\title{
PENGARUH BUDAYA TERHADAP PANGAN, SISTEM BUDAYA TERHADAP MAKANAN, MASALAH BUDAYA DAN MAKANAN TERHADAP GIZI, SERTA SOLUSI MENGATASI MASALAH BUDAYA DAN MAKANAN TERHADAP GIZI DAN KESEHATAN
}

\author{
Jumriatun Naillah \\ Universitas Islam Negeri Alauddin Makassar \\ Jalan.Dr.Ratulangi no.101 \\ Kota Makassar, Sulawesi Selatan, 91871 \\ Email : jumriatunnaillah101@gmail.com
}

\section{PENGARUH BUDAYA TERHADAP PANGAN}

Adanya berbagai jenis makanan dari setiap komunitas dan wilayah di masyarakat. Jenis makanan yang terdapat di wilayah yang satu dengan wilayah lainnya dapat berbeda sesuai dengan kebudayaan di wilayah tersebut. Contoh kebiasaan masyarakat di wilayah Papua dalam mengonsumsi sagu, sehingga banyak olahan makanan yang mereka hasilkan dari sagu, seperti papeda, es cendol sagu, kue bahwa sagu dan lain sebagainya. Pengaruh budaya lain seperti kebiasaan orang Indonesia mengonsumsi nasi, sehingga banyak pula olahan dari nasi seperti nasi kuning, nasi goreng, dan masih banyak lagi. Sedangkan jika dibandingkan dengan negara India, bahan pangan pokok mereka adalah gandum, sehingga menghasilkan olahan Gandung seperti chapatti. Kebudayaan ini memberikan pengaruh yang sangat besar terhadap pangan dan olahan pangan dari suatu wilayah, hal ini juga bergantung pada sumber daya alam yang melimpah di wilayah tersebut, seperti di Papua banyak di tumbuhi pohon sagu, di Indonesia produksi padi sangat berlimpah sehingga menjadikannya sebagai bahan pokok dalam berbagai olahan makanan di Indonesia.

\section{SISTEM BUDAYA TERHADAP MAKANAN}

Sistem budaya terhadap makanandapat dilihat dari berbagai aspek, yaitu;(1) Sifat makanan (Larangan makan makanan tertentu). Misalnya larangan mengonsumsi daun kelor bagi wanita yang hamil muda karena dipercaya dapat menggugurkan kandungannya. Kelor atau biasa disebut Moringa terdiri atas beberapa bagian, mulai dari akar, kulit kayu, bunga, hingga daun. Beberapa bagiannya seperti akar, bunga, dan kulit kayu diketahui tidak aman untuk dikonsumsi baik saat kehamilan maupun ketika menyusui. Hal ini karena kandungannya bisa membuat rahim berkontraksi. Ini bisa membuat ibu hamil mengalami keguguran, khususnya 
bila kehamilan masih berada dalam usia yang muda. Namun sebetulnya, kandungan gizi yang terdapat pada daun kelor memiliki asupan yang dibutuhkan oleh tubuh. Seperti protein, Vitamin, dan antioksidan, namun perlu juga dibatasi puntuk konsumsi sehari-hari agar kandungan gizi yang terdapat di dalamnya dapat membawa kebaikan bagi tubuh. (2) Hidangan makanan (menyajikan makanan pada kegiatan tertentu seperti upacara adat). Misalnya tradisi Puputan di Jawa. Tradisi puputan merupakan tradisi yang dilakukan dalam rangkaian kelahiran seorang anak. Upacara ini menandai putusnya tali pusar si bayi (puput artinya lepas). Waktu untuk penyelenggaraan upacara ini tidak ada ketentuan yang pasti, hal ini bergantung pada lama dan tidaknya tali pusar si bayi lepas dengan semdirinya. Tali pusar bayi dapat lepas sebelum seminggu bahkan bisa lebih dari seminggu. Sehingga keluarga si bayi harus siap mengadakan upacara puputan jika sewaktu-waktu tali pusar tersebut lepas. Biasanya, tradisi ini diselenggarakan dengan mengadakan kenduri atau selamatan yang dihadiri oleh kerabat dan tetangga terdekat. Sesajian (makanan) yang disediakan dalam upacara puputan antara lain nasi gudangan yang terdiri dari nasi dengan lauk pauk, sayurmayur dan parutan kelapa, bubur merah, bubur putih dan jajan pasar. (3) Mengonsumsi makanan dalam keluarga (pemerataan). Distribusi makanan dalam keluarga sangat berpengaruh terhadap kualitas gizi dalam keluarga. Misalnya pada saat bayi, sang ibu paham betul akan pentingnya pemberian ASI kepada bayi untuk menunjang pertumbuhan nya selama dua tahun. Namun pendistribusian makanan dalam keluarga ini juga dapat dipengaruhi oleh pengetahuan dan wawasan mengenai gizi, serta faktor ekonomi penunjangnya.

\section{MASALAH BUDAYA DAN MAKANAN TERHADAP GIZI}

Dilihat dari budaya dan makanan terhadap gizi, maka dapat dikatakan jika budaya makanan tersebut baik misalnya budaya umat Islam dan orang Indonesia pada umumnya yang makan menggunakan tangan ternyata memberi dampak positif bagi tubuh, karena pada jari-jari tangan terdapat bakteri yang dapat membantu proses pencernaa, serta budaya makan ini menunjukkan sikap kesederhanaan. Selain itu, pendistribusian makanan yang baik dalam keluarga memberi dampak yang besar yang berkaitan dengan masalah gizi seperti, contoh masalah dari budaya dan makanan terhadap gizi yaitu terjadinya malnutrisi. Malnutrisi adalah keadaan patologis akibat kekurangan atau kelebihan secara relatif maupun absolut satu atau lebih zat gizi. Kekurangan dan kelebihan gizi muncul karena pola makan bergizi tidak seimbang. Kekurangan gizi terjadi akibat asupan gizi di bawah kebutuhan tubuh, sedangkan kelebihan gizi timbul karena asupan gizi melebihi kebutuhan tubuh. Penyakit akibat malnutrisi seperti, sunting (kekurangan gizi). Stunting adalah kondisi gagal pertumbuhan pada anak akibat kekurangan gizi dalam waktu yang lama. Menurut WHO, Indonesia termasuk ke dalam negara1ketiga dengan prevalensi tertinggi di regional Asia Tenggara /South-East Asia Regional (SEAR). Rata-rata1prevalensi balita stunting di Indonesia tahun 2005-2017 adalah 36,4\%, sehingga persentase balita pendek di Indonesia masih tinggi. Menurut Riskesdas tahun 2018, provensi sualawesi selatan masih berada di angka 35,4\% , dengan kabupaten Enrekang tertiggi ke-5 dengan persentase 42\%. Data PSG tahun 2018 menunjukkan bahwa kecamatan yang memiliki prevalensi stunting tertinggi yaitu Kecamatan Baraka sebesar 45,1\%. Sedangkan Kelebihan gizi atau overnutrisi berisiko menyebabkan penyakit degeneratif seperti diabetes melitus, stroke dan kanker.

\section{SOLUSI MENGATASI MASALAH BUDAYA DAN MAKANAN TERHADAP GIZI DAN KESEHATAN}


Dengan munculnya berbagai masalah terkait kekurangan maupun kelebihan gizi yang disebabkan oleh budaya dan makanan, maka solusi yang dapat dipakai yaitu dengan memperbaiki cara budaya dan makanan yang dikonsumsi dari yang kurang sehat menjadi lebih sehat dan bernutrisi. Misalnya pada saat ini budaya mengonsumsi makanan siap saji (junk food) banyak terjadi di perkotaan yang masyarakatnya dinamis dan membutuhkan sesuatu yang instan. Maka hal tersebut tentu mendatang berbagai masalah kesehatan seperti obesitas, jantung koroner, dan sebagainya. Maka solusi yang dapat diterapkan pada kasus ini adalah dengan melakukan pendekatan sosial serta penyuluhan akan makanan yang bergizi dan seimbang serta menciptakan tren gaya hidup sehat melalui berbagai media, salah satunya media sosial, pada saat ini penggunaan media sosial sudah tidak dapat dipisahkan dari kehidupan masyarakat khususnya di perkotaan, maka dari itu melakukan kampanye hidup sehat melalui media sosial cukup efektif untuk mengedukasi masyarakat tentang budaya dan makanan yang bergizi untuk tubuh. Selanjutnya yaitu dapat melakukan seminar, seminar ini memberikan kita ruang untuk menyampaikan hal-hal yang berkaitan dengan kesehatan dan gizi masyarakat secara langsung serta dapat melakukan tanya jawab langsung untuk mencari solusi terhadap suatu penyakit yang berkaitan dengan masalah gizi dan kesehatan. Selain itu juga terdapat upaya pemerintah dalam menangani masalah gizi di Indonesia berupa, Perbaikan Gizi Keluarga (UPGK) merupakan bentuk upaya yang dilakukan Pemerintah Indonesia melalui Badan Perencanaan Pembangunan Nasional (Bappenas). UPGK merupakan upaya yang dilakukan untuk memperbaiki gizi masyarakat.

\section{DAFTAR PUSTAKA}

Pena018. 2018. “Tradisi Adat Puputan”, https://kimpena.kabpacitan.id/tradisi-adat-puputan/, diakses pada tanggal 8 Desember 2021 pukul 20.01 WITA.

Ibrahim, Irvani Anwar, Syamsul Alam dkk. 2021. "Hubungan Sosial Budaya Dengan Kejadian Stunting Pada Balita Usia 24-59 Bulan Di Desa Bone-Bone Kecamatan Baraka Kabupaten Enrekang Tahun 2020”,

https://scholar.google.com/citations?view_op=view_citation\&hl=id\&user=5xW4cx4AAAAJ \&citation_for_view $=5 \times$ W4cx4AAAAJ:kNdYIx-mwKoC , diakses pada tanggal 8 Desember 2021 pukul 20.29 WITA.

Sari, Siska Permata.2019. "4 Cara Pemenuhan Gizi Untuk Mencegah Stunting Dan Obesitas" , https://www.inews.id/lifestyle/health/4-cara-pemenuhan-gizi-untuk-mencegah-stunting-danobesitas, diakses pada tanggal 8 Desember 2021 pukul 20.49 WITA. 